\title{
Takeoff and Landing Control using Force Sensor by Electrically-Powered Helicopters
}

\author{
Masanori Fujita Student Member (Polytechnic University, m17517@uitec.ac.jp) \\ Akira Shimada Senior Member (Polytechnic University, ashimada@uitec.ac.jp)
}

Keywords: helicopter, control, force sensor, system identification, takeoff and landing, disturbance observer

This paper introduces a takeoff and landing control technique using a helicopter. The used control system consists of a small toy electrically-powered helicopter for indoor flights, a flight base under which a focre sensor is set, and a helicopter control terminal which is connected to a system controller. The reason of the force sensor use is to realize soft takeoff and landing control. When the helicopter stands on the base, the force sensor outputs force data corresponding to the weight of the helicopter. As the operational voltage rises, the helicopter almost takes off from the base. Concurrently, the forse sensor output closes to 0 . It means that lift force related to force sensor output becomes from $0 \mathrm{~N}$ to the value cprresponding to the weight. Therefore, when the system controller controls the lift force by changing the operational voltage, it can be expected to realize the soft takeoff and landing control. This paper introduces the design process including system modeling and shows the simulation and experimental results.

Fig. 1 shows appearance of the system structure. Fig. 2 shows the system identification result. Fig. 3 indicates a block diagram of lift force digital control system. It consistes of the plant which means the helicopter, digital disturbance observer, and the digital LQ servo controller. Fig. 4 shows the experimental result of lift force control of the helicopter. This result indicates that the controller realizes the intended characteristics.

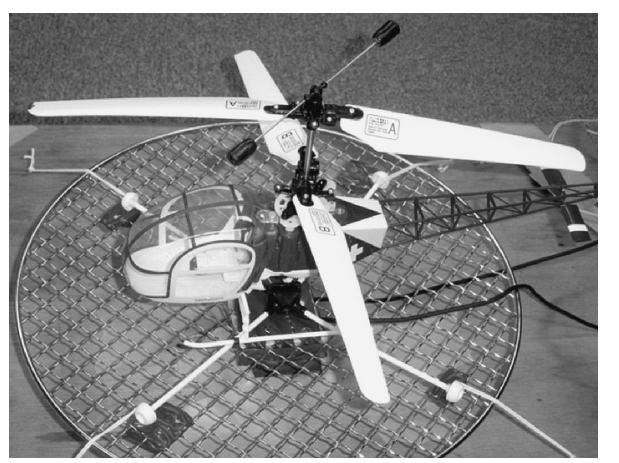

Fig. 1. Helicopter on a netted base with force sensor

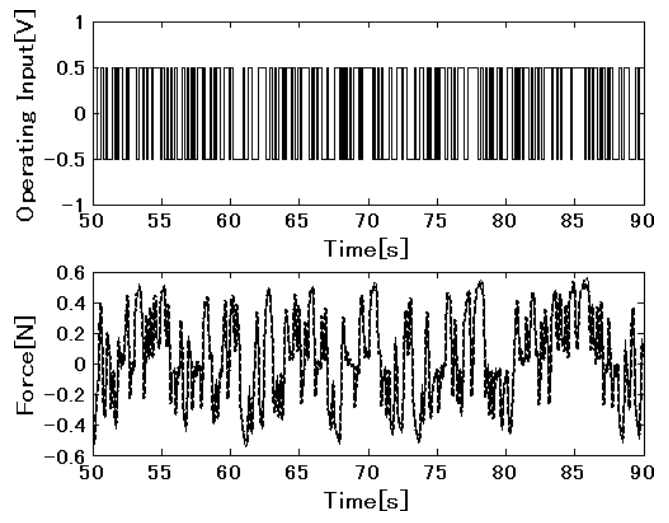

Fig. 2. System identification result

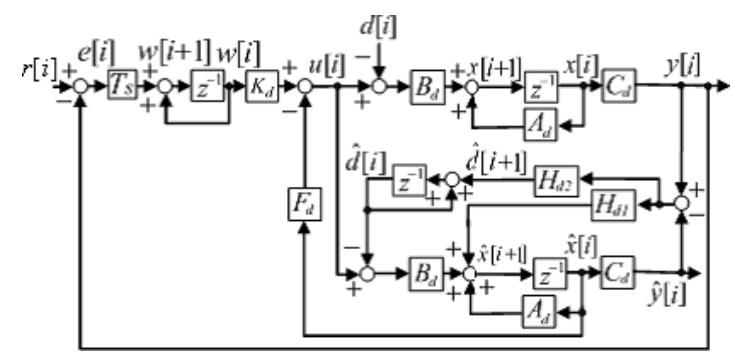

Fig. 3. Block diagram of lift force digital control system
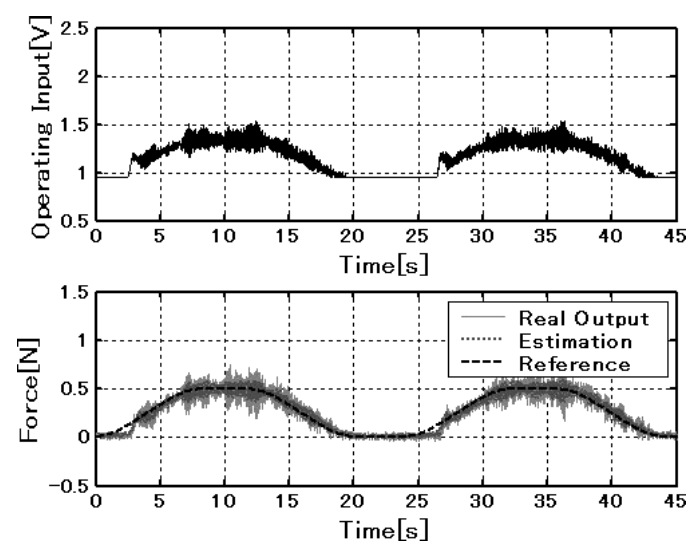

Fig. 4. Experimental result 


\title{
カセンサを用いた電動へリコプタの離着陸制御
}

学生員 藤田 真宜* 上級会員 島田＼cjkstart明*

\section{Takeoff and Landing Control using Force Sensor by Electrically-Powered Helicopters}

\author{
Masanori Fujita*, Student Member, Akira Shimada*, Senior Member
}

\begin{abstract}
This paper introduces a takeoff and landing control technique related to a helicopter. The presented control system consists of a small toy electrically-powered helicopter for indoor flights, a flight base under which a focre sensor is set, and a helicopter control terminal which is connected to a system controller. The force sensor use is intended to realize soft takeoff and landing control. When the helicopter stands on the base, the force sensor outputs lift force data corresponding to the weight of the helicopter. As the operational voltage rises, the helicopter almost takes off from the base. Concurrently, the forse sensor output closes to 0 . Thus, if the system controller controls the voltage arbitrarily, it is expected to realize the soft takeoff and landing control. This paper introduces the design process including modeling based on ststem identification technique, and shows the simulation and experimental results of the lift force control.
\end{abstract}

キーワード：ヘリコプタ, 制御, カセンサ, システム同定, 離着陸, 外乱オブザーバ

Keywords: helicopter, control, force sensor, system identification,takeoff and landing, disturbance observer

\section{1. はじめに}

ヘリコプタには狭い場所での離着陸や静止飛行が可能で ある等の特長があり, 様々な物資の運搬用に使われる他，山 岳地帯, 海上等で広く利用されている ${ }^{(1)(2)}$ 。通常, ヘリコプ 夕は有人運転が基本であるが，遠隔運転によるものも実用 化されている。また, 近年, 災害地域や危険地帯でのへリ コプタの自律制御技術が求められるようになり，同制御技 術の実用化が求められている。しかしながら，ヘリコプタ は飛行機に比して, 安定性が悪く, 自動制御・自律制御が困 難な移動機械であることも知られている。これまで，足立， 野波らによる先駆的な研究事例が報告されているが(3) (9), 同技術はまだまだ発展途上にある。

本稿では, ヘリコプタ制御研究への一つの取り掛かりと して, 室内用の玩具として製品化されている小型電動へリ コプタを題材とし, 力センサを利用した鉛直方向 $(\mathrm{z}$ 方向 $)$ の柔らかい離着陸制御を試みるものである(10)(11)。図 1 にそ のイメージを示す。同技術の用途としては，崩れかけた脆 い場所での離着陸や波に摇れる船舶上への離着陸等が考え られる。前者は着陸点に衝撃を与えないために用いられ， 後者は着陸点の位置自体が時間と共に変化する場合であっ て，ヘリコプタの自重全部をかけることが望ましくないよ

\footnotetext{
*職業能力開発総合大学校電気システム工学科

于 229-1196 相模原市橋本台 4-1-1

Dept. of Electrical System Engineering, Polytechnic University

4-1-1, Hashimotodai, Sagamihara-shi 229-1196
}

うな着陸点への離着陸が考えられる。このように，同技術 は今後のへリコプタ制御の一つの可能性を示すものである。 また，同技術は風力を利用した沉用的な力制御技術として， ヘリコプタ以外の用途に用いても良いと考えられる。

システムの構成要素としては, 電動へリコプタ本体, ヘリ ポートに当たるベース, ベース下部に接続される力センサ, ヘリコプタを手動操作するための操作盤, システム全体を 自動制御するためのシステムコントローラが挙げられる。 本稿では, 揚力制御のみを扱うが, 最終的には, 視覚セ ンサを用いる位置制御機能を付加する予定である。すなわ ち, 離陸後に揚力制御から位置制御に切り替え, 着陸時に ヘリコプタ下端が接地した時点から, 揚力值が自重值から 0 值まで滑らかに変化する揚力制御に切り替えるモード切 り替え制御技術の確立を目標としている。本稿では，この

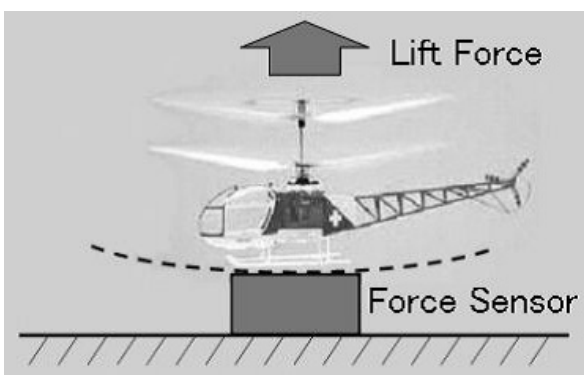

図 1 ヘリコプタ揚力制御のイメージ

Fig. 1. Image of helicopter lift force control. 
揚力制御を離着陸制御と呼ぶことにする。

\section{2. 離着陸システムの仮定が表す意味と制約条件}

図 1 のように,ヘリポートの基部に力七ンサを配置する 仮定は，現実的でないと思われるかもしれない。これに対 し，二通りのケースが想定される。第一のケースは，大型 のロードセルを実際にヘリポートに設置する場合である。 しかし，これは特別なケースであると考えられる。第二の ケースは，カセンサをへリコプタに装備するケースである。 これは，一見，仮定と異なるようであるが，へリコプタの 見かけ上の自重を所望の值に制御する目的を適える点で等 価である。本例ではへリコプタ自体が小型軽量であるため

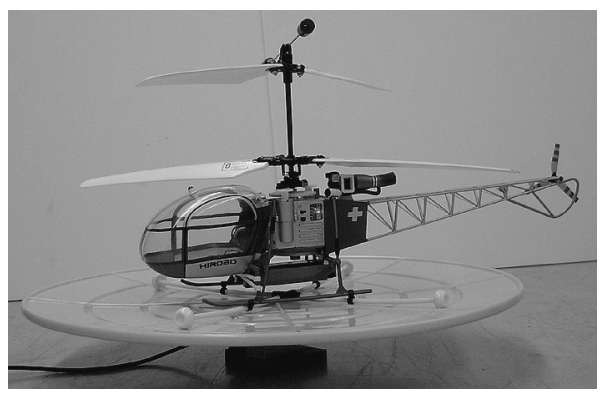

図 2 カセンサを持つ面状ベース上のヘリコプタ

Fig. 2. Helicopter on a plate base with force sensor.

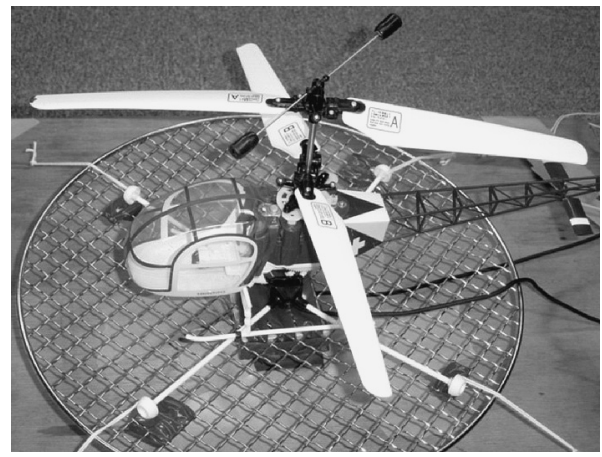

図 3 カセンサを持つ網状ベース上のヘリコプタ

Fig. 3. Helicopter on a netted base with force sensor.
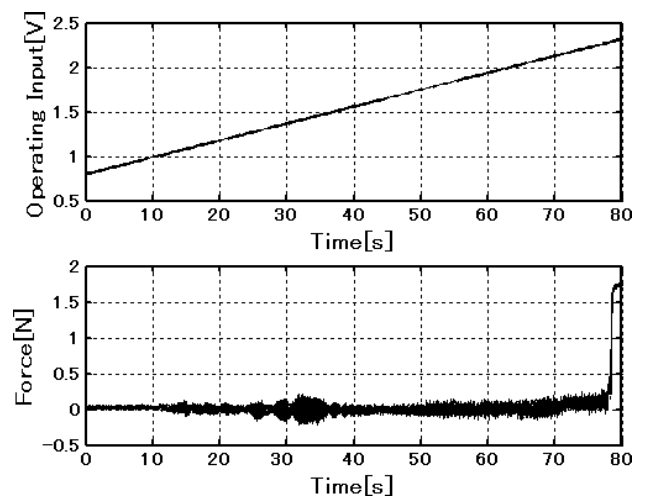

図 4 面状ベースでの操作電圧と力センサ出力

Fig. 4. Operational voltage and force output on the plate base.
に，カセンサを搭載できない。このように，本稿の仮定は， 主に，第二のケースを実現するための代替手段である。

第二のケースと本実験装置の構成を力学的に等価なもの とするためには，条件が必要である。それは，図 2 のよう に,ヘリポートを面状のベースとするのではなく, 図 3 の ように，網状のベースとして作成し，ブレードが発生する 風力をへリポートが直接に受けないようにすることである。 そうしないと, ブレードの回転速度の増加に伴い,ヘリコプ 夕の揚力も増すが, 風力をへリポートが受けてしまい, 力 センサはヘリコプタの自重と風力とを合わせて観測してし まう。図 4 はその様子を示しており, 操作電圧が $2.3 \mathrm{~V}$ 付 近まで, 力センサ出力が $0 \mathrm{~N}$ (自重に相当する) 付近を維持 している。これに対し，網状ベースを用いた場合は，図 5 のように, 操作電圧と力センサ検出值がほぼ線形になる。 このとき, ヘリコプタは操作電圧約 $0.95 \mathrm{~V}$ から揚力が上昇 し始め, 約 $2.2 \mathrm{~V}$ から浮上をし始める。操作電圧が約 $2.4 \mathrm{~V}$ に至ると,ヘリコプタが完全に浮上して飛行状態に入るが, その浮上直前の揚力は約 $1.5 \mathrm{~N}$ である。

\section{3. システム構成とモデリング}

本稿では，実験用のヘリコプタとして，ヒロボー（株） 製の小型の室内用のラジコン電動へリコプタ X.R.B を用い る。同機は 2 組のメインロータが同軸上に配置され，互い に反転して姿勢の維持を図ることから，同軸反転方式と呼 ばれる。姿勢の変更は, 両メインロータの駆動トルク差に より, 回転数の差を発生させて行い, テールロー夕を必要 としない。上部メインロータは，ヘリコプタの若干の傾き によらずに水平に保たれるため傾き難い。同へリコプタは, 通常, 図 6 に示す操作盤を用いて, オペレータにより遠隔操 作される。主な操作手段は, 操作盤上の 2 本のレバーを手 動で傾けて行われる。各レバーは前後左右に傾く 2 自由度 構造を有し, 自由度毎に可変抵抗器に接続されている。す なわち, 合計 4 組の可変抵抗器により, 操作電圧が増減さ れ，ヘリコプタが操縦される。ヘリポートに当たるべース 上にヘリコプタが静止すると, ベースの下に設置した力セ
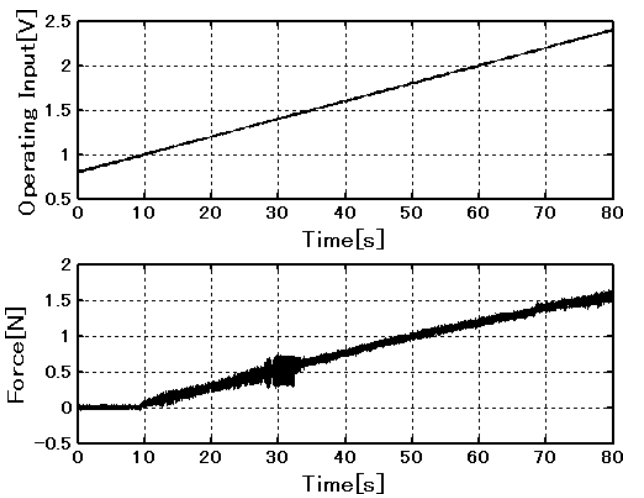

図 5 網状ベースでの操作電圧と力センサ出力

Fig. 5. Operational voltage and force output on the netted base. 


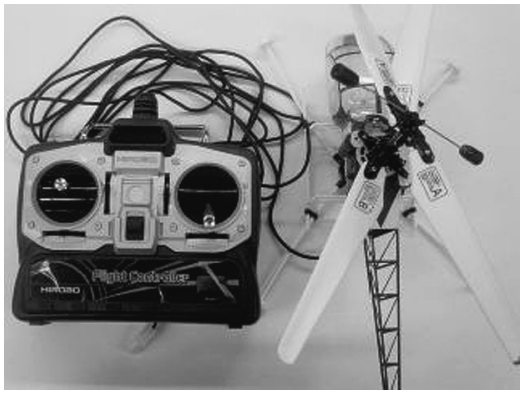

図 6 操作盤とヘリコプタ

Fig. 6. Operational unit and helicopter.

ンサよりヘリコプタにかかる重力とベースの重力とが検出 されるが，実験時には，ベースの重力は検出值から差し引 く。ヘリコプタを飛行させるために, 操作盤の操作電圧を 印加してメインロー夕を回転させると，回転速度が上がる に連れて揚力が増す。その一方で，力センサの出力は減少 し, 完全に離陸して飛行状態に入ると力センサ出力は $0 \mathrm{~N}$ となる。そこで, カセンサによる力検出值がへリコプタ重 力值から 0 值に向けて滑らかに減少するような力制御，す なわち，揚力が 0 值から自重値に至る揚力制御を行う。

さて, ヘリコプタのモデリングを行うためには，動力学 的なアプローチを試みることが望ましい。しかしながら， それは決して容易でないことが既報告等に報告されており， その対策として，M系列信号を用いたシステム同定法が使 用されることが多い(3) (6)。本研究でも，既報告に倣って， 同定実験によりモデル化を行うことにする ${ }^{(12)}$ 。飛行時と接 地時とでは異なる数学モデルが必要であろうが，本稿では 後者のモデリングのみを扱う。

具体的には，操作電圧から力センサ出力までのシステム の特性を同定する。同定には, 表 1 に示すように, カセンサ 出力がヘリコプタにかかる重力の半分程度の值をオフセッ トとする $\mathrm{M}$ 系列信号電圧を用い，部分空間同定法の一つで ある N4SID 法により，制御対象の数学モデルを集中定数 系の定係数線形系のモデルとして求める。 $\mathrm{M}$ 系列信号電圧 の振幅とオフセットは，図 5 に見られる波形の中の，線形 性が保たれる範囲で定めた。同信号のサンプル周期は，ス テップ状操作電圧に対する力応答波形の時定数が約 $1.0 \mathrm{~s}$ で あったことから，その $1 / 10$ 倍程度とした。データの獲得 は, $0.01 \mathrm{~s}$ 毎に 10000 点行った後, デシメーションを行い, $0.1 \mathrm{~s}$ 毎の 1000 点とした。さらに，デトレンド処理により 平均值を除き，平均值から離れた初めの 100 点を除き，前 半の 450 点データでシステム同定演算を行い，状態方程式 を作成した後に，後半の 450 点で検証を行った。

まず，インパルス応答法により，インパルス応答推定波 形を調べると, $t=0[\mathrm{~s}]$ の時点から正方向への振幅が始ま るまでに 2 サンプルを要しているので， $0.02 \mathrm{~s}$ のむだ時間 遅れがあることが確認できる。図7(a) を参照のこと。

次に，同定時の入出力デー夕列と，むだ時間デー夕を 用いて, N4SID 法により, 離散系状態方程式 $G_{d}(z)=$
表 1 システム同定条件

Table 1. System identification condition.

\begin{tabular}{l|l}
\hline Amplitude and offset of M sequence & $\pm 0.5 \mathrm{~V}, \pm 1.5 \mathrm{~V}$ \\
\hline Sampling ratio of M sequence & $0.1 \mathrm{~s}$ \\
\hline Sampling ratio of data acquisition & $0.01 \mathrm{~s}$ \\
\hline Number of Datas (by decimation) & 1000 \\
\hline Order of N4SID & 4 \\
\hline
\end{tabular}

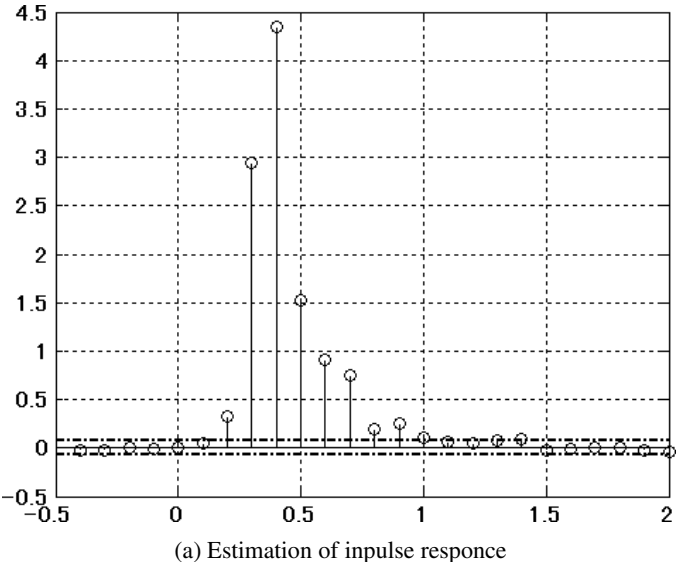

(a) Estimation of inpulse responce
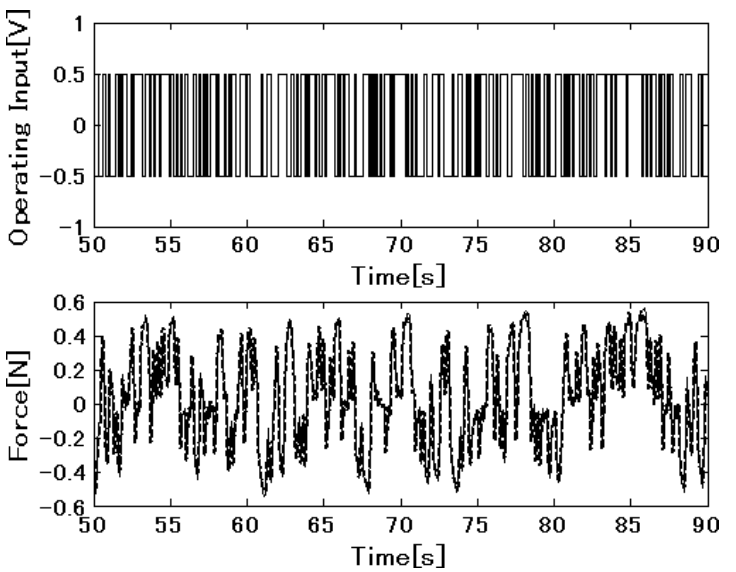

(b) Response and Estimation for M sequece input

図 7 システム同定結果

Fig. 7. System identification result.

$\left\{A_{d}, B_{d}, C_{d}, D_{d}\right\}$ を得た。このとき，一旦，実験時のサンプ 儿周期 $0.1 \mathrm{~s}$ で同定した数学モデルを, 改めて, $0.001 \mathrm{~s}$ をサ ンプル周期とする 4 次系モデルとして, 再サンプリング処 理を行った。その結果を図 7(b) に示した。上段が M 系列 信号, 下段が $\mathrm{M}$ 系列信号に対する実出力と, 同定モデルの 出力波形を重ね書きしたものである。共にデシメーション 処理をしたため, 平均值が 0 值になっている。点線が実出 力, 実線がモデル出力であるが，ほぼ重なっており，両波 形の FIT 率は $91.5 \%$ である。得られた制御対象モデルの数 值例は以下の通りである。同定した制御対象モデルを，状 態変数 $x[i] \in R^{4}$, 操作電圧 $u[i] \in R$, 力七ンサ出力 $y[i] \in R$, サンプル周期 $T_{s}=0.001[\mathrm{~s}]$ とする。留意すべきは，同モ デルはむだ時間特性を含んでいる点である。

$$
x[i+1]=A_{d} x[i]+B_{d} u[i]
$$




$$
\begin{aligned}
y[i]= & C_{d} x[i] \ldots \ldots \ldots \ldots \ldots \ldots \ldots \ldots \ldots \ldots \ldots \ldots \ldots \\
A_{d}= & {\left[\begin{array}{llll}
a_{11} & a_{12} & a_{13} & a_{14} \\
a_{21} & a_{22} & a_{23} & a_{24} \\
a_{31} & a_{32} & a_{33} & a_{34} \\
a_{41} & a_{42} & a_{43} & a_{44}
\end{array}\right] \ldots \ldots \ldots \ldots \ldots 0^{-2}, } \\
a_{11}= & 1.0051, a_{12}=-1.4598 \times 10^{-3}, \\
a_{13}= & -1.3808 \times 10^{-2}, a_{14}=9.2188 \times 10^{-1}, \\
a_{21}= & 2.3288 \times 10^{-2}, a_{22}=9.6405 \times 10^{-2}, \\
a_{23}= & -3.1308 \times 10^{-2}, a_{24}=2.4534 \times 10^{-2}, \\
a_{31}= & -2.5612 \times 10^{-2}, a_{32}=3.5141 \times 10^{-2}, \\
a_{33}= & 1.0556, a_{34}=-4.2752 \times 10^{-2}, \\
a_{41}= & -5.1666 \times 10^{-2}, a_{42}=8.4131 \times 10^{-2}, \\
a_{43}= & 1.2661 \times 10^{-1}, a_{44}=9.2984 \times 10^{-1} \\
B_{d}= & {\left[-7.7754 \times 10^{-4},-4.3330 \times 10^{-3},\right.} \\
& \left.4.9742 \times 10^{-3}, 1.0470 \times 10^{-2}\right]^{T} \\
C_{d}= & {\left[4.5346,3.0015,0.3775,-2.7371 \times 10^{-2}\right] } \\
D_{d}= & 0
\end{aligned}
$$

\section{4. 外乱オブザーバ併合型制御系と目標軌道の設計}

同定モデルを用いて，揚力制御系設計を行うと共に，揚力 の目標軌道を設計する。様々な制御法の選択が可能である が，本稿では外乱オブザーバ併用型ディジタル LQ サーボ 系 ${ }^{(13)}$ を設計することとした。留意すべき点として，システ 厶同定は, 入出力波形から統計数学的な手法を用いて, 制御 対象の数学モデルを導き出す手法であるため, 同定された モデルの状態変数が, 位置や速度に代表されるように, 物理 的に意味を持つ変数になってないことである。つまり，そ れらをセンサを用いて観測することができない。そのため, 状態フィードバックを利用する構造の制御系を設計しよう とするならば，オブザーバを用いて状態変数を推定する必 要がある。一方, 制御対象は, パラメー夕変動を有し, 未 知の外乱を受けるものである。その結果，通常のオブザー バを使用すると，無視し難い推定誤差が発生する心配があ る。そこで，それらの物理的な影響を全て入力端への外乱 に見立て, 状態空間表現によるディジタル外乱オブザーバ を設計して対処することとした。入力端外乱 $d[i]$ を含めた 状態方程式は次のように書き表される。

$$
\begin{aligned}
& x[i+1]=A_{d} x[i]+B_{d}(u[i]-d[i]) \\
& y[i]=C_{d} x[i] \cdots \ldots \ldots \ldots \ldots \ldots
\end{aligned}
$$

次に, サンプル周期 $T_{s}$ 間で外乱の值が変化しないと仮定 し, 外乱 $d[i+1]=d[i]$ とおいて, 拡大系を作成する。

$$
\begin{aligned}
& {\left[\begin{array}{l}
x[i+1] \\
d[i+1]
\end{array}\right]=\left[\begin{array}{cc}
A_{d} & -B_{d} \\
0 & I
\end{array}\right]\left[\begin{array}{l}
x[i] \\
d[i]
\end{array}\right]+\left[\begin{array}{c}
B_{d} \\
0
\end{array}\right] u[i]} \\
& y[i]=\left[C_{d}, 0\right]\left[\begin{array}{l}
x[i] \\
d[i]
\end{array}\right] \ldots \ldots \ldots \ldots \ldots \ldots \ldots
\end{aligned}
$$

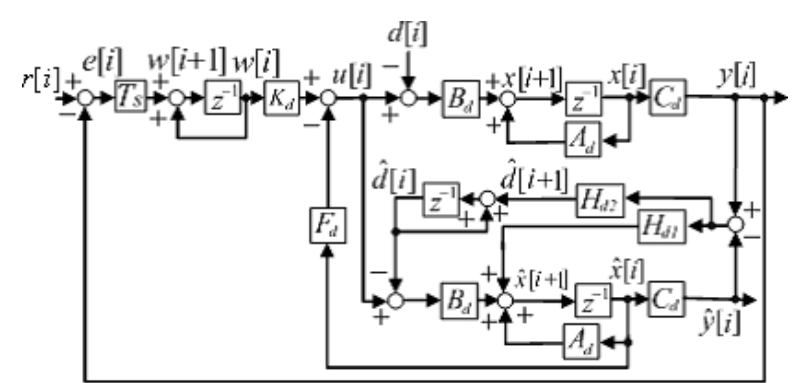

図 8 揚力制御系のブロック図

Fig. 8. Block diagram of lift force control system.

次に，同一次元ディジタル外乱オブザーバを設計する。

$$
\begin{aligned}
& {\left[\begin{array}{c}
\hat{x}[i+1] \\
\hat{d}[i+1]
\end{array}\right]=} {\left[\begin{array}{cc}
A_{d} & -B_{d} \\
0 & I
\end{array}\right]\left[\begin{array}{c}
\hat{x}[i] \\
\hat{d}[i]
\end{array}\right]+\left[\begin{array}{c}
B_{d} \\
0
\end{array}\right] u[i] } \\
&+\left[\begin{array}{c}
H_{d 1} \\
H_{d 2}
\end{array}\right](y[i]-\hat{y}[i]) \ldots \ldots \ldots \ldots \\
& \hat{y}[i]=\left[C_{d}, 0\right]\left[\begin{array}{c}
\hat{x}[i] \\
\hat{d}[i]
\end{array}\right] \ldots \ldots \ldots \ldots \ldots \ldots
\end{aligned}
$$

ディジタル LQ サーボ系を構成する制御入力, すなわち, 操作電圧 $u[i]$ は次のように表される。 $r[i]$ は目標揚力值, $y[i]$ は揚力観測值, $e[i]$ は制御偏差, $w[i]$ は偏差の積分值, $F_{d}$ はフィードバックゲイン行列, $K_{d}$ は積分ゲインである。

$$
\begin{aligned}
& e[i]=r[i]-y[i] \cdots \ldots \\
& w[i+1]=w[i]+T_{s} \cdot e[i] \\
& u[i]=-F_{d} \hat{x}[i]+K_{d} w[i] \cdots
\end{aligned}
$$

図 8 に制御系のブロック図を示した。偏差から積分演算 に至る間の $T s$ ブロックは連続系と同じ重み関数 $Q, R$ を用 いても, 積分ゲインが連続系の LQ サーボ系のゲインとほ ぼ一致する働きを持たせるために設けている ${ }^{(13)}$ 。

次に, 揚力の目標軌道設計について述べる。離着陸を滑 らかに柔らかく実施するために，ロボット制御でよく用い られる 5-1-5 次多項式を用いた揚力の目標軌道を生成し, そ れに制御系を追従させる。具体的には, $0.001 \mathrm{~s}$ 毎に, 静止 状態の 0 值から $7.5 \mathrm{~s}$ 間で目標揚力值に段々と近づいてい き， $5 \mathrm{~s}$ 間その值を維持した後，また $7.5 \mathrm{~s}$ 間かけて，着陸 状態に当たる 0 值に至る目標軌道関数を作成し, それを揚 力制御系への参照值として入力するものとした。

\section{5. シミュレーション及び基礎実験結果}

ヘリコプタの離着陸制御系のシミュレーション結果と基 礎実験結果とを示す。制御パラメータ值を表 2 に記す。

シミュレーションも実験も，基礎的な制御機能の確立を 第一の目標とするため, 飛行臨界点以下の揚力目標值への 追従性を評価した。シミュレーション結果は図 9 に, 実験 結果は困 10 に示した。 $0.5 \mathrm{~N}, 1.0 \mathrm{~N}$ の 2 種類の揚力目標 值に対して実施したシミュレーション結果を見ると，オブ ザーバの揚力推定值も実揚力も目標值に対してよく一致し 
表 2 制御パラメータ值

Table 2. Control parameters.

\begin{tabular}{l|l}
\hline$Q_{d}$ & $\operatorname{diag}(1,1,1,1,10000)$ \\
\hline$R_{d}$ & 100 \\
\hline$F_{d}$ & {$[11.185,-1.6821,-0.5787,0.5254]$} \\
\hline$K_{d}$ & 9.9652 \\
\hline Poles of observer & {$[0.976,0.977,0.978,0.979,0.980]$} \\
\hline$H_{d 1}$ & {$\left[1.0077 \times 10^{-2},-6.9012 \times 10^{-3}\right.$,} \\
& $\left.-4.1040 \times 10^{-3}, 9.8193 \times 10^{-3}\right]^{T}$ \\
\hline$H_{d 2}$ & $-4.4683 \times 10^{-2}$ \\
\hline
\end{tabular}
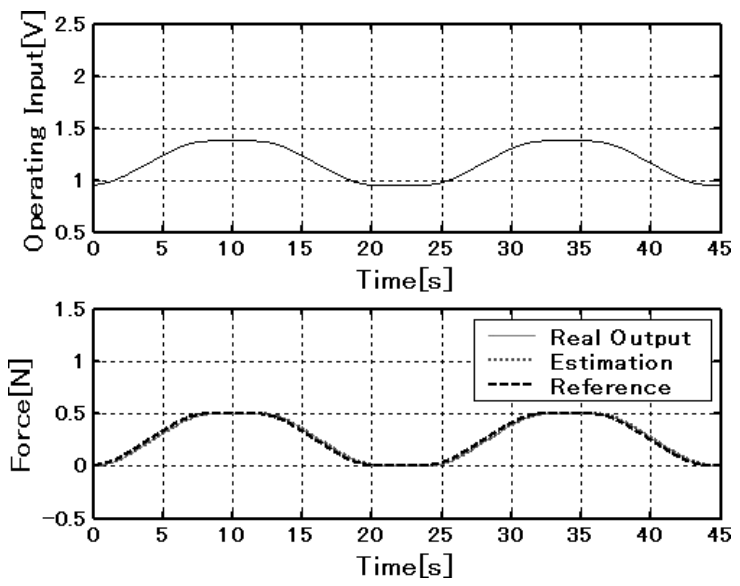

(a) Lift force $0.5 \mathrm{~N}$
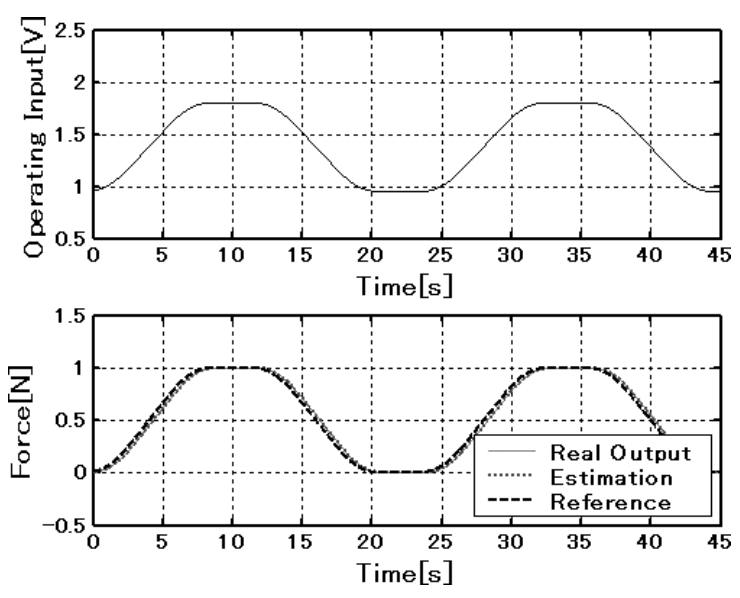

(b) Lift force $1.0 \mathrm{~N}$

図 9 揚力制御のシミュレーション結果

Fig. 9. Simulation result of lift force control.

ており，良好な制御機能が実現されていることがわかる。

次に実験結果について考察する。実験も $0.5 \mathrm{~N}, 1.0 \mathrm{~N}$ の 2 種類の揚力目標值に対して実施した。細い実線が揚力目 標值であり，前章で記したように5-1-5 次多項式を利用し た滑らかな形状が見られる。揚力波形を観察すると，揚力 目標值が 0 值から上昇し始める際には，0 值のまま全く追 従しない区間がわずかあり，その後，目標值に追従してい る。また，目標値が自重の半分程度にあたる $0.5 \mathrm{~N}$ の波形 の方が, 浮上臨界点に近い $1.0 \mathrm{~N}$ に比して, 安定性が高く, 高精度に追従していることがわかる。これは，同定条件に 近い動作点での制御が行われているためであると思われる。
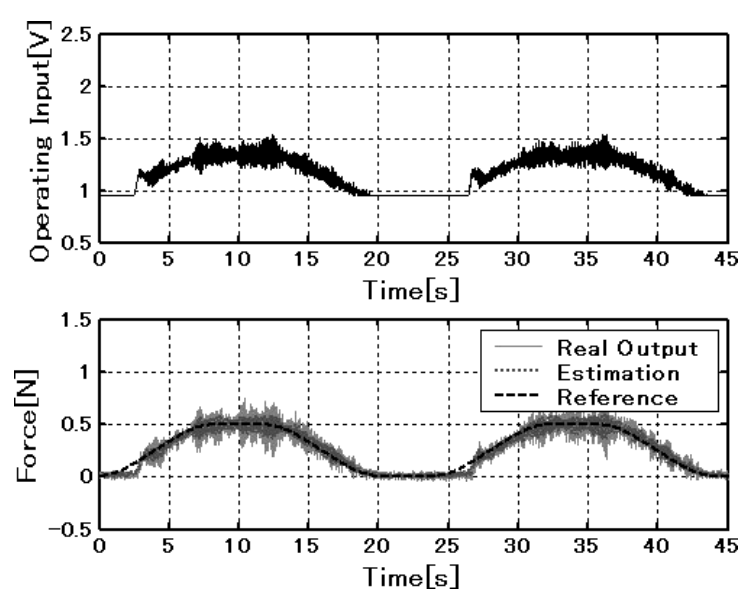

(a) Lift force $0.5 \mathrm{~N}$
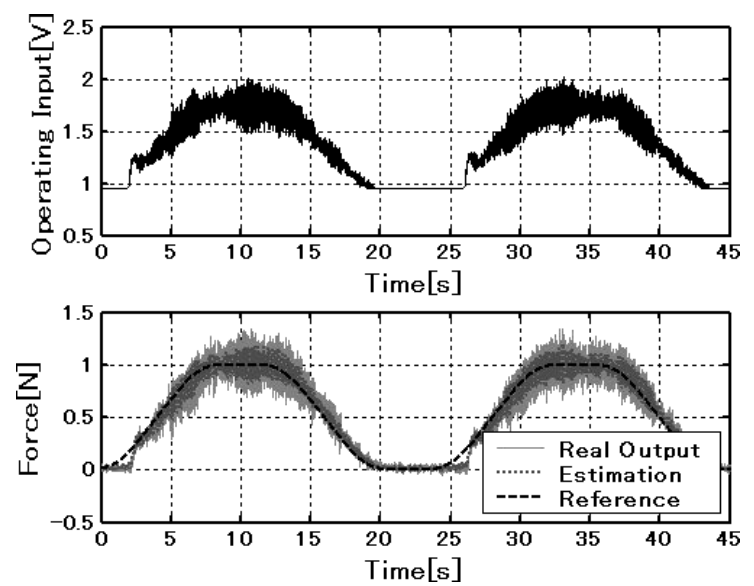

(b) Lift force $1.0 \mathrm{~N}$

図 10 揚力制御の実験結果

Fig. 10. Experimental result of lift force control.

総合的に見ると，いずれのデータもシミュレーション結 果とほほ一致する入力, 出力波形を表しており, 設計理論 に即したシステムが実現できていると考えられる。

\section{6. おわりに}

ヘリコプタ制御系の研究に関し，離着陸時の揚力制御系 設計のためのモデリング法と制御系設計法, シミュレーショ ン結果，そして実験結果を報告した。その結果，ヘリコプ 夕の操作電圧を制御入力とする揚力制御が実現可能である ことが示された。しかしながら，同制御を成功させるため には, 機体の丁寧なメンテナンスが必要であり, ブレード のバランス調整を欠いた機体に対して同制御法を実現する と, ヘリコプタは振動を発生し, 力制御波形も顕著な振動 を示すものとなった。また, 揚力目標值の違いに対して制 御結果に差異が見られることから, 将来は, 同制御法のロ バスト性を向上させるための工夫が必要であると考えられ る。また今後は, 最終目標である, 離着陸時の力センサ情 報を用いた揚力制御と, 飛行時の視覚センサ情報に基づく 位置制御とを併せて実現し, 両者を切り替えるモード切り 替え制御技術の確立を進める予定である。 


\section{謝 辞}

有益なご教授・ご助言をいただいた千葉大学工学部の野 波健蔵教授と王 偉氏に感謝します。

(平成 17 年 9 月 28 日受付，平成 18 年 6 月 27 日再受付)

\section{文献}

(1) 加藤宽一郎：「ヘリコプタ入門」, 東京大学出版会 (1985)

（2）金井喜美雄他：「ビークル」, 計測自動制御学会編, コロナ社 (2003)

(3) S. Adachi, S. Hashimoto, G. Miyamori, and A. Tan: "Autonomous flight control for a large-scale unmanned helicopter-System identification and robust control systems design", 電学産業応用部門誌, Vol.121-D, No.12, pp.1278-1283 (2001)

(4) J. Shin, D. Fujiwara, K. Hazawa, and K. Nonami: "Attitude Control and Hovering Control of Radio-Controlled Helicopter", Trans. of JSME-C, Vol.68, No.675, pp.3284-3291 (2002) (in Japanese)

辛 振玉・藤原大悟・羽沢健作・野波健蔵：「ラジコンヘリコプタ の姿勢制御・ホバリング制御」,日本機械学会論文集 (C 編), 68, 675, pp.3284-3291 (2002)

(5) K. Hazawa, J. Shin, D. Fujiwara, K. Igarashi, D. Fernando, and K. Nonami: "Autonomous Flight Control of Hobby-Class Small Unmanned Helicopter", Trans. of JSME-C, Vol.70, No.691, pp.720-727 (2004) (in Japanese) 羽沢健作・辛 振玉 - 藤原大悟・五十嵐一弘・D. Fernando - 野波健 蔵:「ホビー用小型無人ヘリコプタの自律制御」, 日本機械学会論文 集 (C 編), 70, 691, pp.720-727 (2004)

(6) D. Fujiwara, J. Shin, K. Hazawa, and K. Nonami: "Ho Hovering and Guidance Control for Autonomous Small-Scale Unmanned Helicopter”, Trans. of JSME-C, Vol.70, No.694, pp.1708-1714 (2004) (in Japanese) 藤原大悟・辛 振玉 ・羽沢健作・野波健蔵：「自律小型無人ヘリコプ タの $\mathrm{H} \infty$ ホバリング制御㧍よび誘導制御」, 日本機械学会論文集 $(\mathrm{C}$ 編), 70, 694, pp.1708-1714 (2004)

(7) H. Nakanishi, K. Inoue, and A. Sato: "Development of Aerial Information Gathering Methods at a Disaster Area”, JRSJ, Vol.22, No.5, pp.546-549 (2004) (in Japaense)

中西弘明・井上紘一・佐藤 彰：「被災地に打ける空からの情報収集 技術の確立」, 日本ロボット学誌, 22, 5, pp.546-549 (2004)

(8) W. Wang, M. Hirata, K. Nonami, and O. Miyazawa: "Autonomous Hovering Control and Guidance Control of Microminiature Ultra-Lightweight MicroFlying Robot", Proc. of Mechanical Engineering Congress 2005 (MECJ05), Vol.7, pp.275-276, JASME (2005) (in Japanese) 王 偉 ·平田光男・野波健蔵・宮澤 修:「超小型・超軽量マイクロ フライングロボットの自律ホバリング制御と誘導制御」, 日本機械学 会年次大会講演論文集 (7), pp.275-276, 日本機械学会 (2005)

(9) K. Nakata, M. Miwa, and K. Tokuda: "Aerial Photograpghing with Remote Control Support System", Proc. of Mechanical Engineering Congress 2005 (MECJ-05), Vol.7, pp.279-280, JASME (2005) (in Japanese)
中田健太・三輪昌史・徳田献一：「リモートコントロールサポート システムを使った航空撮影」, 日本機械学会年次大会講演論文集 (7), pp.279-280, 日本機械学会 (2005)

(10) M. Fujita and A. Shimada: "Helicopter Controller Design making Use of Vision Sensor", IIC-05-78, IEEJ (2005) (in Japanese)

藤田真宜・島田 明：「視覚センサを利用したヘリコプタ制御系の 設計」, 電気学会産業計測制御研資, IIC-05-78, 電学 (2005)

(11) M. Fujita and A. Shimada: "Helicopter Takeoff and Landing Control using Force Sensor", Proc. of Mechanical Engineering Congress 2005 (MECJ-05), Vol.7, pp.273-274, JASME (2005) (in Japanese)

藤田真宜・島田 明：「力センサを用いたヘリコプタ離着陸制御系 の設計」, 日本機械学会年次大会講演論文集 (7), pp.273-274, 日本機 械学会 (2005)

（12）足立修一：「MATLAB による制御のためのシステム同定」,東京電機 大学出版局 (1996)

(13) A. Shimada, K. Ohishi, M. Shibata, and O. Ichikawa: "IEEJ EE Text Motion Control”, IEEJ, Ohmusha (2004) (in Japanese)

島田 明・大石 潔・柴田昌明・市川 修:「電気学会 EE テキスト モーションコントロール」,オーム社 (2004)

藤 田 真 宜 (学生員) 1982 年 5 月生。 2005 年 3 月職業能力

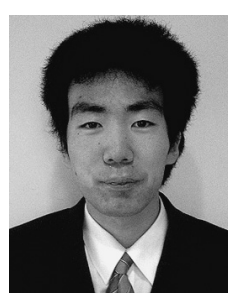
開発総合大学校電気工学科卒業。同年 4 月職業能 力開発総合大学校研究課程（修士課程）電気情報 専攻入学。モーションコントロール, 非線形制御, ヘリコプタ制御系の研究に従事。

島 田 明 (上級会員) 1958 年 9 月生。1983 年 3 月電気通

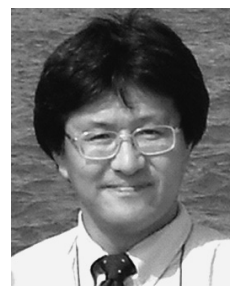
信大学電子工学科卒業。同年 4 月（株）第二精工 舎（現・セイコーインスッル（株））に入社し，ロ ボットコントローラ開発に従事。1994 年 4 月よ り葉大学非常勤講師を兼務, 1999 年 4 月より 客員教授を兼務。2001 年 4 月より職業能力開発 総合大学校電気システム工学科助教授。IEEE, 計 測自動制御学会, 日本ロボット学会等の会員, 博 士 (工学) (1996 年, 慶応義塾大学)。 